\title{
Konsep Bimbingan Konseling Anak Usia Dini Serta Alternatif Medianya Melalui Permainan Tradisional
}

\author{
Frendi Fernando \\ STAI Sufyan Tsauri Majenang
}

DOI : https://doi.org/10.15642/jeced.v2i1.536

\begin{abstract}
Guidance and counseling in early childhood institutions should not only be given to those who have problem behaviors, but must also be given to children who are in the process of growth and development. In early childhood, guidance and counseling is based on how to make the child's growth reach an optimal point, both physical motor, psychological and socio emotional. The process is mostly done by playing, singing, dancing and others. Traditional games can be used as a medium of guidance and counseling for early childhood. Types of traditional games are very good for children's development such as dexterity, creativity, social, and so on. In terms of benefits, traditional game is certainly very different from most modern games today, which do not use physical activity (silence) by staring at mobile screens and individualists, which of course results in the physical, and socio emotional development and physical growth of children not running optimally. For this reason, it is necessary to preserve the traditional game culture through creativity in order to preserve local wisdom as well as efforts to develop media for guidance and counseling for young children.
\end{abstract}

\begin{tabular}{l}
\hline Abstrak \\
Pada dasarnya bimbingan konseling (BK) di lembaga anak usia dini tidak bisa \\
hanya diberikan kepada mereka yang mempunyai perilaku bermasalah, akan \\
tetapi sudah menjadi keharusan diberikan pula kepada mereka (seluruh anak \\
didik) yang memang sedang dalam masa golden age. BK pada anak usia dini \\
didasarkan pada bagaimana agar tumbuh kembang anak mencapai titik yang \\
optimal, baik fisik motorik, psikis maupun sosio emosionalnya. Prosesnya \\
banyak dilakukan dengan metode bermain, bernyanyi, menari dan lain-lain. \\
Terdapat berbagai macam media BK untuk anak usia dini, salah satunya \\
adalah melalui permainan tradisional. Ini dikarenakan beberapa jenis \\
permainan dalam permainan tradisional sangat baik untuk mengoptimalkan \\
perkembangan anak seperti meningkatkan ketangkasan, kerjasama, \\
kreatifitas, dan lain sebagainya. Dari segi manfaat, tentu permainan \\
tradisional sangat berbeda dengan kebanyakan permainan modern saat ini. \\
Permainan modern lebih banyak tidak menggunakan aktifitas fisik (berdiam \\
diri) dengan menatap layarhandphone dan cenderung individualis, yang tentu \\
saja mengakibatkan perkembangan dan pertumbuhan fisik dan sosio \\
emosional anak tidak berjalan optimal. Untuk itulah perlunya kembali \\
melestarikan budaya permainan tradisional melalui kreatifitas demi \\
melestarikan kearifan lokal sekaligus sebagai upaya pengembangan media \\
bimbingan konseling untuk anak usia dini.
\end{tabular}

\section{Article Info}

Article history:

Received: 21042020

Accepted: 04062020

Published online: 15062020

Keywords:

early childhood counseling guidance

media counseling guidance

traditional games local wisdom

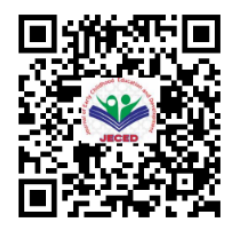

\begin{tabular}{l}
\hline Informasi Artikel \\
\hline Riwayat Artikel \\
Revisi terakhir: 21042020 \\
Diterima: 04062020 \\
Publikasi online: 15062020 \\
\hline
\end{tabular}

\section{Kata kunci:}

bimbingan konseling anak usia dini

media bimbingan konseling permainan tradisional 


\section{PENDAHULUAN}

Pendahuluan tidak diberi judul, ditulis langsung setelah abstrak. Bagian ini menyajikan kajian pustaka yang berisi paling sedikit tiga gagasan: (1) latar belakang atau rasional penelitian, (2) masalah dan wawasan rencana pemecahan masalah, (3) rumusan tujuan penelitian (dan harapan tentang manfaat hasil penelitian).

Sebagai kajian pustaka, bagian ini harus disertai rujukan yang dapat dijamin otoritas penulisnya. Jumlah rujukan harus proporsional (tidak terlalu sedikit dan tidak terlalu banyak). Pembahasan kepustakaan harus disajikan secara ringkas, padat, dan langsung mengenai masalah yang diteliti. Aspek yang dibahas boleh landasan teorinya, segi historisnya atau segi lainnya. Penyajian latar belakang atau rasional hendaknya sedemikian rupa sehingga mengarahkan pembaca ke rumusan masalah penelitian yang dilengkapi dengan rencana pemecahan masalah dan akhirnya ke rumusan tujuan. Untuk penelitian kualitatif, bagian ini dijelaskan juga fokus penelitian dan uraian konsep penelitian dan uraian konsep yang berkaitan dengan fokus penelitian (Purnama, 2016, p.20).

\section{METODE}

Masa keemasan (golden age) adalah waktu dimana anak-anak akan sangat peka terhadap rangsangan apapun yang datang dari luar dirinya. Setiap rangsangan tersebut sangat berpengaruh terhadap pertumbuhannya secara fisik, maupun perkembangannya psikisnya. Usia 2-6 tahun merupakan usia saat kemampuan fisik motorik dan kognitif anak sedang berkembang secara maksimal. Anak sebagai peniru yang hebat, menjadikan apapun disekitarnya sebagai role model dalam berperilaku. Terkadang anak menjadi sangat baik ataupun sebaliknya, anak menjadi emosional, dan perkembangan secara psikisnya terganggu akibat tidak semua orang tua bisa memahami dan mengantisipasi segala bentuk gangguan psikis pada anak.

Browder L memperkirakan 5 - 10\% anak-anak memiliki gangungan emosional (ED). Anakanak dengan gangguan emosional nantinya akan cenderung memiliki hambatan keberhasilan dalam bidang akademis, khususnya dibidang membaca, menghitung, bahasa dan ekpsresi tertulis. Hal ini tentu tidak bisa dibiarkan saja, karena akan sangat mempengaruhi keoptimalan perkembangan anak. Jika melihat banyaknya permasalahan dalam tahapan perkembangan anak usia dini, maka sudah selayaknya layanan bimbingan dan konseling di lembaga-lembaga setingkat PAUD sangat diperlukan (Iswantiningtyas, 2017, p.390).

Asumsi dasar yang melandasi bahwa sebenarnya lembaga setingkat PAUD, TK atau RA memerlukan program bimbingan konseling adalah karena adanya kesetaraan pendidikan untuk anak usia dini dengan pendidikan dasar dan menengah. Setara yang dimaksud disini adalah setara pada tingkat permasalahan yang dihadapi, meskipun tentu saja masalah tersebut sesuai taraf tingkatan usianya. Jika selama ini dilingkungan pendidikan dasar dan menengah program bimbingan dan konseling sangat dibutuhkan, maka pada tingkatan PAUD juga pasti membutuhkannya. Untuk itulah diperlukan ketrampilan dan keahlian dalam bidang bimbingan konseling untuk pendidik dalam hal ini pendidik pada tingkatan PAUD. Program bimbingan konseling untuk anak usia dini nantinya diarahkan dengan tujuan membantu anak agar perkembangan anak berjalan dengan normal, anak juga dapat berinteraksi dan bersosialisasi dengan teman-temannya di sekolah. Biasanya dimulai pada saat awal masuk sekolah yang umumnya anak-anak akan sedikit banyak mengalami kesulitan bersosialisasi. Maka dengan bantuan guru/ pendamping melalui beberapa program bimbingan maupun konseling anak diajak berinteraksi dengan teman-temannya dalam suasana yang menyenangkan (Iswantiningtyas, 2017, p.391).

Selain pentingnya keahlian dan pengalaman dari pendidik PAUD, faktor lain dalam menunjang keberhasilan bimbingan kepada anak adalah faktor intern dari pendidik itu sendiri. Faktor intern yang dimaksud adalah rasa tulus dan perhatian pada anak, berminat pada problem 
tumbuh kembangnya, berupaya mengembangkan potensi yang dimiliki pada anak, bersikap hangat dan yang terpenting adalah bersedia melebur dengan dunia yang dimiliki anak-anak. Bermain dengan dunia anak, tentunya pendidik juga harus dapat memilih permainan-permainan apa saja yang dapat menunjang perkembangan baik fisik maupun psikis dari anak didik.

Tujuan penulisan ini ialah agar pembaca dapat memahami pengertian dari bimbingan konseling anak usia dini terlebih dahulu, kemudian dapat memahami pelayanan apa yang seharusnya diterapkan dalam bimbingan konseling anak usia dini dan memahami bagaimana penerapan layanan itu sendiri sesuai dengan kebutuhan yang diperlukan, serta alternatif permainan yang dapat menunjang perkembangan fisik motorik, kognitif, bahasa dan sosio-emosional pada anak usia dini, dalam hal ini melalui beberapa jenis dalam permainan Tradisional.

\section{HASIL PENELITIAN DAN ANALISIS}

Jenis penelitian ini adalah penelitian kepustakaan (library research) sehingga teknik pengumpulan data yang digunakan menggunakan metode dokumentasi, yaitu peneliti berusaha mencari data mengenai hal-hal atau variabel yang terdapat dalam penelitian. Data dapat berupa catatan, buku, transkip, surat kabar, prasasti, notulen rapat, agenda dan lain sebagainya (Arikunto, 1997, p.236). Prosesnya dilakukan dengan cara membaca, menelaah, dan memahami beberapa sumber, seperti buku-buku, karya ilmiah, jurnal dan sumber ilmiah lainnya yang berhubungan dengan bimbingan konseling anak, psikologi anak dan permainan untuk anak usia dini.

Penelitian ini menggunakan analisis isi atau content analisys (Muhadjir, 1998, p.62). Teknik ini dipergunakan karena penelitian ini termasuk penelitian kepustakaan. Data-data yang telah peneliti peroleh kemudian diinterpretasikan sehingga peneliti mendapatkan gambaran yang pada gilirannya dapat diangkat sebagai kesimpulan penelitian. Langkah-langkah teknik analisis data dalam penelitian ini meliputi:

1. Peneliti melakukan pengumpulan data-data penelitian dari sumber-sumber yang relevan.

2. Data-data penelitian yang terkumpul dideskripsikan dalam penyajian data.

3. Analisis dilakukan dengan teknik menganalisis data-data yang disajikan dengan teori-teori yang dikemukakan dan hasilnya disajikan dalam pembahasan penelitian untuk selanjutnya diambil kesimpulan.

\section{PEMBAHASAN}

\section{Bimbingan dan Konseling Anak Usia Dini}

Bimbingan dan konseling merupakan suatu proses dalam membantu individu mengatasi hambatan - hambatan perkembangan dirinya sehingga dapat mencapai perkembangan kemampuan pribadinya secara optimal. Jika hubungannya dengan anak, maka bimbingan konseling anak merupakan proses yang terjadi antara anak dan seorang konselor dalam hal ini guru/ pendamping dalam membantu anak-anak agar dapat memahami apa yang terjadi kepada mereka serta membantu agara anak mencapai perkembangan dan pertumbuhan yang optimal. Konseling yang dimaksud tentu berbeda dengan proses konseling yang biasa dilakukan dengan orang dewasa. Konseling dengan anak dilakukan dalam proses pembelajaran maupun permainan, serta dengan media-media yang ada disekitar dan disukai oleh anak-anak.

Pada proses bimbingan dan konseling perlu ditekankan bahwa anak harus merasa hubungan dirinya dengan konselor dalam hal ini gurunya sendiri adalah hubungan yang bisa dipercaya, dan lingkungan konseling adalah lingkungan yang aman. Agar hal ini terjadi, guru sebagai konselor harus bersikap terbuka, membumi, tulus, konsisten, dan optimis sehingga rasa percaya diri bisa dikembangkan dan dipertahankan. Hal ini perlu dipersiapkan karena anak-anak akan sangat pandai mengenali orang yang tidak kongruen denganya atau mencoba berpura-pura dan tidak konsisten dengan kepribadiannya (Geldard, 2012, p.9). 
Perlu diktahui bersama bahwa proses / program bimbingan dan konseling di lembaga PAUD tidak hanya diberikan kepada mereka yang mempunyai perilaku bermasalah, akan tetapi juga harus diberikan kepada anak yang sedang dalam proses pertumbuhan dan perkembangan. Sehingga konseling anak bukan hanya dilaksanakan untuk mengatasi perilaku bermasalah pada anak didik, melainkan juga tindakan untuk memenuhi kebutuhan tumbuh kembangnya secara maksimal sebagai sebuah langkah preventif (Suryadi, 2010, p.165). Pelaksanaan bimbingan dan konseling anak usia dini tidak hanya dilakukan melalui bimbingan khusus, namun dapat dilakukan dalam berbagai kegiatan seperti bermain, karya wisata, leaflet, dan lain sebagainya.

Pelaksanaan layanan dan konseling di PAUD tentu tidaklah sama seperti pelaksanaan konseling di sekolah SMP atau SMA, karena anak usia dini masih sangat membutuhkan perhatian yang lebih, baik dari guru maupun orang tua. Pada prosesnya memerlukan keseriusan bagaimana membangun suasana yang nyaman bagi anak.

Berikut ini beberapa teknik yang dapat dilakukan dalam proses bimbingan konseling anak usia dini, meliputi:

1. Aktif

Belajar merupakan suatu proses yang aktif dari anak dalam membangun pengetahuannya. Belajar bukan hanya proses pasif yang hanya menerima dari guru saja. Guru diharapkan mampu membangun suasana yang sedemikian rupa sehingga anak dapat bereaksi dengan aktif baik itu aktif untuk bertanya, mendengar maupun mempertanyakan mengenai apa yang dibahas serta berani mengemukakan gagasan (Saintifik). Perlu diketahui bahwa anak justru akan lebih cepat lelah jika belajar hanya duduk diam dibandingkan dengan anak yang berlari, melompat, atau lainnya. Maka, dengan proses pembelajaran yang aktif, motorik halus dan motorik kasar anak akan berkembang dengan baik.

2. Kreatif

Kreatif merupakan suatu daya cipta dimana seseorang memiliki kemampuan untuk berkreasi. Sikap kreatif ini pada suatu saat akan menghasilkan generasi yang mampu menciptakan sesuatu untuk kepentingan dirinya dan kepentingan orang lain. Kreatif yang dimaksud juga agar guru dapat kreatif menciptakan kegiatan-kegiatan belajar yang beragam.

3. Efektif

Pembelajaran yang efektif terwujud karena pembelajaran yang dilaksanakan dapat menumbuhkan daya kreatif. Tujuannya adalah agara kemampuan yang diperoleh tidak saja hanya berupa pengetahuan biasa, namun merupakan kemampuan yang lebih bermakna, sehingga menghasilkan kemampuan dan potensi yang beragam. Belajar yang efektif dapat dicapai dengan tindakan dan aktiftas nyata, karena aktifitas bermain dengan bereksplorasi dapat membangun perkembangan kognitif, bahasa, dan sosio emosional.

4. Menyenangkan

Menurut hasil penelitian oleh para ahli, tingginya perhatian anak terhadap guru dan proses pembelajaran terbukti dapat meningkatkan hasil belajar. Dalam proses belajar, harus tercipta suasana pembelajaran yang menyenangkan sehingga anak dapat memusatkan perhatiannya secara utuh. Situasi dan kondisi yang menyenangkan dapat mengaktifkan otak untuk berfikir dan mengoptimalkan proses belajar serta yang lebih penting lagi adalah meningkatkan kepercayaan diri anak sehingga suasana pembelajaran terbangun dengan aktif dan efektif. Sebaliknya, suasana kelas yang cenderung kaku, penuh ketegangan, justru akan menurunkan fungsi otak pada anak yang tentu saja anak tidak dapat berfikir lagi secara optimal.

Berdasarkan hal tersebut diatas, perlu dikembangkan program pendidikan yang disesuaikan dengan keadaan masing-masing anak. Dalam hal ini adalah mengenai pelayanan bimbingan dan konseling untuk membantu mengenal keadaan pribadi masing-masing anak dan kemudian membantu mengembangkan program-programnya. Program yang dikembangkan ini bisa berupa program individu ataupun program kelompok, seperti program kegiatan menyanyi, menari, 
permainan musik tradisional, kegiatan ketrampilan, dan sebagainya, yang semuanya itu bersifat pilihan (Adhiputra, 2013, p.55).

\section{Kriteria Konselor Anak}

Program Kegiatan Belajar Taman Kanak-Kanak (PKBTK) 1994 dan 2002 menyatakan bahwa bimbingan di taman kanak-kanak adalah proses bantuan khusus yang diberikan petugas dalam hal ini oleh guru kepada peserta didik dalam rangka memperhatikan kemungkinan adanya hambatan atau kesulitan yang dihadapi anak dalam rangka mencapai perkembangan yang optimal (Adhiputra, 2013, p.27).

Guru pada tingkat lembaga anak usia dini harus bisa sesuai dengan kriteria yang diinginkan bagi konselor anak, diantaranya adalah (Geldard, 2011, p.27):

1. Kongruen

Kongruen yang dimaksud adalah anak-anak harus menganggap dan merasa hubungannya dengan konselor sebagai hal yang bisa dipercaya dirasa aman. Untuk itu konselor harus bisa terintegrasi secara personal, rendah hati, konsisten, bersikap wajar dan stabil. Hal ini dikarenakan anak-anak akan sangat pandai mengenali orang yang tidak kongruen dan yang sedang mencoba memainkan suatu peranan yang tidak konsisten dengan kepribadian dirinya yang sesungguhnya.

2. Berhubungan dengan sisi kekanakannya

Dunia orang dewasa tentu sudah berbeda dengan dunia anak. Namun pada dasarnya orang dewasa tidak akan kehilangan sisi anak-anak, karena masih akan menjadi bagian dari kepribadian. Menemukan dan berperilaku dengan sisi anak-anak tidak berarti menjadi kekanakkanakan atau menjadi anak-anak, tetapi berarti berhubungan dengan bagian dari diri yang sesuai dengan dunia anak-anak.

\section{Menerima}

Untuk mendorong anak menggali sisi pribadi atau sisi gelap diri anak, maka konselor harus bersikap dengan cara paling bisa diterima sehingga anak merasa diizinkan untuk menjadi diri mereka, tanpa batasan. Yang dilakukan adalah menerima, dengan sikap yang tidak menghakimi terhadap apapun yang dikatakan dan dilakukan anak-anak.

4. Tidak emosional

Artinya konselor tidak boleh terpengaruh secara emosional dengan masalah anak, yakni konselor juga melakukan pengabaian emosional. Jika konselor terlibat secara emosional, maka konselor akan tertekan dengan masalah yang dirasakan oleh anak. Hal ini akan menambah luka anak saat melihat konselor terluka.

\section{Tujuan Konseling Anak}

Berbeda dengan konseling pada umumnya, konseling pada anak usia dini juga dimaksudkan agar perkembangan psikis dan pertumbuhan fisik anak berjalan secara optimal. Agar konseling dapat berjalan kondusif sesuai dengan tujuan yang ingin dicapai, maka lingkungan tempat dilaksanakannya konseling hendaknya juga diperhatikan. Konseling harus menyesuaikan dengan karakteristik anak usia dini yang identik dengan bermain sehingga membutuhkan tempat konseling yang dikondisikan sesuai dengan karakteristik anak.

Tujuan konseling bagi anak terbagi menjadi 4 (empat), yaitu:

1. Tujuan fundamental

Tujuan tersebut yaitu:

a. Memberdayakan anak-anak agar dapat menghadapi masalah emosional yang menyakitkan

b. Memberdayakan anak-anak untuk mencapai beberapa tingkatan kongruen yang berkaitan dengan pemikiran, emosi dan perilaku dirinya.

c. Memberdayakan anak-anak agar dapat merasa nyaman dengan dirinya (Geldard, 2011, p. 
3)

2. Tujuan orang tua

Tujuan ini dibuat oleh orang tua ketika mereka membawa anak yang biasanya didasarkan pada perilaku terakhir anak- anak. Misalnya, jika seorang anak gemar melumuri kotoran di tembok, maka tujuan orang tua ialah menghilangkan perilaku ini.

3. Tujuan yang dirancang oleh konselor

Tujuan ini dirancang dan disusun oleh seorang konselor sebagai konsekuensi hipotesis mengenai alasan mengapa seorang anak memiliki sikap tertentu. Sebagai contoh misalnya seorang anak yang gemar melumuri kotoran. Konselor mungkin memiliki hipotesis bahwa sikap gemar melumuri itu merupakan akibat dari keadaan emosional anak tersebut. Sehingga konselor kemudian memiliki tujuan untuk mengatasi dan menanggulangi sisi emosional pada anak tersebut.

4. Tujuan anak-anak

Tujuan ini akan muncul selama masa terapi yang merupakan tujuan yang ingin dicapai oleh anak-anak, meskipun biasanya anak tidak mampu untuk mengatakannya secara verbal. Tujuan ini seringkali didasarkan pada benda - benda yang dibawa oleh si anak selama terapi. Tujuan ini bisa saja sesuai dengan tujuan konselor tapi terkadang juga tidak sesuai

\section{Kriteria Media dalam Bimbingan Konseling Anak Usia Dini}

Pada dasarnya dalam pelaksanaan konseling pada anak usia dini, konselor tidak cukup hanya menggunakan keterampilan-ketrampilan verbal saja, namun konselor dapat pula menggunakan berbagai alat, media dan aktivitas sebagai bantuan untuk mencapai tujuan konseling itu sendiri. Kombinasi antara keterampilan konseling verbal serta dengan pemanfaatan media atau beberapa aktivitas atau strategi akan memberikan kesempatan pada anak untuk bergabung dengan konselor dalam proses terapeutiknya. Penggunaan media atau aktivitas memungkinkan anak untuk membagi cerita tentang hal-hal yang sifatnya sensitif sekalipun. Dalam Kathryn Geldard \& David Geldard (Geldard, 2011, p. 217) kriteria media yang digunakan dalam konseling anak diharapkan dapat mengarah pada memfasilitasi anak untuk berkembang pada beberapa aspek berikut:

1. Menguasai masalah dan peristiwa

2. Menjadi kuat melalui ekspresi fisik

3. Mendorong ekspresi emosi

4. Mengembangkan keterampilan pemecahan

5. Masalah dan pengambilan keputusan

6. Mengembangkan keterampilan sosial

7. Membangun konsep diri dan harga diri

8. Meningkatkan keterampilan komunikasi

9. Mengembangkan wawasan.

Setiap media yang digunakan dalam proses terapi tentu memiliki sifat dan manfaat yang berbeda- beda. Geldard dan Geldard mengungkapkan faktor- faktor penting yang perlu diperhatikan dalam memilih media atau aktivitas dalam proses terapi pada anak usia dini. Faktorfaktor tersebut antara lain adalah:

1. Usia perkembangan anak.

2. Bentuk konseling pada anak apakah dilakukan secara individu atau kelompok.

3. Tujuan konseling saat itu untuk anak.

Berdasarkan faktor-faktor tersebut terdapat beberapa media dan aktivitas yang sesuai dengan domain perkembangan anak berdasarkan kelompok usianya. Beberapa media dan aktivitas tersebut diantaranya adalah melalui buku/cerita, tanah lempung, konstruksi, menggambar, permainan, perjalanan khayalan, permainan pura-pura imajinatif, hewan miniatur, melukis dengan jari, menempel, boneka tangan, bak pasir, simbol/figur, lembar kerja dan beberapa lainnya. 
Ada berbagai macam model dan jenis permainan yang dapat digunakan sebagai media dalam meningkatkan kreativitas, sosial emosional, kognitif dan bahasa anak. Salah satu jenis media tersebut adalah permainan tradisional. Permainan tradisional sendiri merupakan simbolisasi dari pengetahuan yang turun temurun dan biasanya mempunyai makna serta bermacam-macam karakter fungsi dibaliknya. Permainan tradisional dihasilkan dari suatu budaya yang mengandung nilai bagi yang memainkannya khususnya bagi anak-anak dalam rangka menumbuhkembangkan kemampuan berimajinasi, berkreasi, berolah raga dan juga sebagai sarana berinteraksi, bersosial, menumbuhkan keterampilan, mengajari kesopanan serta meningkatkan ketangkasan.

\section{Permainan Tradisional Berbasis Kearifan Lokal Sebagai Media Bimbingan Dan Konseling Di PAUD}

Permainan tradisional juga merupakan sebuah satu aset budaya untuk menunjukkan ciri khas kebudayaan suatu bangsa. Pendidikan karakter yang sedang digalakan dalam sistem pendidikan di negara kita dapat dibentuk melalui permainan tradisional sejak usia dini. Karena pada kenyataannya pendidikan budi pekerti yang diajarkan masih sebatas teori dan kurang adanya refleksi dari pengajaran tersebut. Dampaknya, anak-anak akan tumbuh menjadi manusia yang kurang memiliki karakter, bahkan lebih kepada bertingkah laku mengikuti perkembangan zaman tanpa filter.

Permainan tradisional merupakan permainan yang banyak mengandung nilai budaya dan tentunya sangat bermanfaat bagi anak-anak. Ajun Khamdani (Khamdani, 2010, p. 95), menyatakan terdapat beberapa nilai dan manfaat yang terkandung dalam permainan tradisional bagi perkembangan anak, antara lain :

1. Nilai Demokrasi

Permainan tradisional bagi anak dapat mendorong para mereka untuk mengembangkan nilai-nilai demokrasi. Dimana para peserta wajib mengikuti aturan main yang disepakati sebelum permainan dimulai. Sebelum permainan dimulai para peserta harus merundingkan terlebih dahulu mengenai aturan dan tata cara bermain dalam permainan. Berdasarkan hal tersebut itulah secara tidak langsung para peserta sebenarnya diajarkan untuk memiliki jiwa dan nilai demokrasi.

\section{Nilai Pendidikan}

Permainan tradisional juga dapat dimanfaatkan sebagai media untuk memberikan pendidikan jasmani maupun rohani. Permainan tradisional akan menumbuhkan sifat disiplin, sosial, meningkatkan etika dan moral, kejujuran, kemandirian, ketangkasan serta percaya diri. Permainan yang dilakukan secara beregu ini juga dapat memupuk kerjasama sehingga menghindarkan dari sikap egois anak.

3. Nilai Kepribadian

Kegiatan permainan merupakan media untuk mengembangkan dan mengungkapkan jati diri anak. Pembentukan karakter pada anak dapat terbentuk di lingkungan sekolah atau masyarakat melalui permainan. Pada permainan tradisional terdapat aspek tertentu yang dapat membentuk kepribadian. Aspek tersebut meliputi aspek jasmani (fisik), rohani (psikis) serta aspek sosial. Permainan tradisional yang banyak mengandung aspek jasmani akan sangat bermanfaat dalam melatih keterampilan motorik anak. Kemudian jenis permainan tradisional terutama yang membutuhkan interaksi dan hubungan langsung antar peserta juga dapat mengembangkan aspek sosial dan emosional. Selain itu permainan tradisional juga akan melatih kemampuan berkomunikasi yang dapat menumbuhkan sifat kepemimpinan pada diri anak. Aspek psikis yang berkembang meliputi unsur berpikir, kecerdasan, daya ingat, serta kreativitas. Sementara itu aspek sosial yang berkembang meliputi unsur kerja sama, saling menghormati, keteraturan, serta kepedulian sosial.

4. Nilai Keberanian 
Kegiatan bermain melalui permainan tradisional mengandung nilai-nilai keberanian karena setiap peserta akan dituntut untuk memiliki sikap berani dan percaya diri. Sikap ini dimaksudkan dalam berani mengambil keputusan dan memperhitungkan strategi tertentu secara spontan agar dapat memenangkan permainan dalam permainan tersebut.

5. Nilai Kesehatan

Permianan merupakan suatu kegiatan yang mengandung unsur fisik motorik kasar seperti berlari dan melompat serta banyak aktifitas untuk menggerakkan otot-otot tubuh. Sehingga tanpa disadari kegiatan tersebut membantu dalam menjaga kesehatan anak. Anak yang sehat akan dapat terlihat dari kelincahan dalam gerakan-gerakannya. Tidak hanya itu, emosi yang terpendam dalam jiwa juga dapat disalurkan melalui kegiatan bermain tersebut.

6. Nilai Persatuan

Masyarakat Indonesia pada dasarnya memiliki prinsip hidup selaras dengan sesama serta hidup bermasyarakat yang dilandasi kerukunan, saling pengertian dan tenggang rasa. Prinsip-prinsip ini juga tercermin dalam beberapa permainan tradisional. Misalnya pada permainan gobak sodor, permainan ini adalah sebuah permainan yang memerlukan kerja sama dan kekompakan tim untuk mencapai kemenangan. Oleh karena itu, setiap anggota kelompok harus mempunyai rasa solidaritas kelompok yang tinggi.

7. Nilai Moral

Nilai moral yang terkandung dalam permainan tradisional berkaitan dengan nilai filosofis dari permainan tersebut yaitu membentuk kepribadian anak. Melalui kegiatan permainan, anak dikenalkan dengan kultur atau budaya bangsanya. Selain itu, anak juga dapat memahami pesan moral yang terkandung di dalam permainan tersebut.

Berikut ini beberapa jenis permainan tradisional yang menurut peneliti dapat dimainkan atau dipraktikan dalam rangka menumbuh kembangkan aspek fisik, psikis, bahasa dan sosial emosional anak usia dini, dan mudah dalam pembuatan dan pengaplikasiannya, diantaranya:

1. Bakiak

Permainan Bakiak tentu tidak asing lagi ditelinga masyarakat Indonesia. Bakiak sendiri dikenal sebagai alas kaki. Biasanya, bahan Bakiak terbuat dari kayu yang kuat tetapi ringan. Bentuknya sesuai dengan telapak kaki, lalu diberi tali yang terbuat dari kulit atau karet. Sebagian alat permainan Bakiak bentuknya panjang dan talinya pun lebih dari satu yang sudah disesuaikan dengan jumlah pemainnya. Permainan tradisional Bakiak berada pada kategori permainan yang bersifat bermain serta beradu ketangkasan, karena sifat permainannya yang mengandalkan ketangkasan kaki serta mengandalkan kekompakan dari masing-masing pesertanya (Ismail, 2006, p. 325).

Permainan tradisional Bakiak pada dasarnya memiliki karakteristik yang sama dengan permainan tradisional yang lain, namun dalam permainan bakiak mempunyai karakteristik khusus yang tidak sama dengan permainan-permainan tradisional yang lain. Permainan Bakiak ini tidak memerlukan alat atau bahan yang mahal untuk bisa memainkannya, bahan-bahannya dapat dengan mudah ditemukan di lingkungan sekitar sehingga tidak membutuhkan biaya dan bahan yang mahal untuk membuatnya. Pada dasarnya permainan tradisional bakiak dimainkan oleh 1-3 orang atau maksimal 5 orang saja. Permainan ini sangat bersifat kompetitif sehingga semakin banyak pemain tentu akan semakin menarik permainannya (Prantoro, 2015, p. 21).

Aturan permainan bakiak diantaranya yaitu (Pontjopoetro, S. Dkk. 2002):

a. Sebelum perlombaan dimulai, usia para peseta diteliti untuk menentukan kelompok usia. Regu yang sudah diteliti kelompok usianya, kemudian diberi nomor (dua) untuk dipasang di dada bagi peserta yang paling depan dan di punggung pemain paling belakang;

b. Peserta dibagi dalam regu yang terdiri dari 5 orang atau 3 orang sesuai dengan jenis yang diperlombakan; 
c. Seluruh peserta dibagi dalam seri setiap seri maksimal 5 regu sesuai dengan jumlah lintasan (disesuaikan dengan jumlah regu peserta);

d. Selanjutnya diadakan undian untuk menentukan lintasan masing - masing regu, dan untuk menentukan urutan pemberangkatan dalam perlombaan;

e. Sebelum perlombaan dimulai, peserta dari masing - masing regu berdiri dibelakang garis start di samping terompahnya;

f. Aba - aba dalam perlombaan diberikan oleh juri pemberangkatan adalah bersedia, siap, ya (peluit dibunyikan atau bendera start dikibarkan). Petugas lintasan berdiri dibelakang peserta dan memperhatikan regu pada lintasan masing - masing dengan membawa bendera biru merah;

g. Pada aba - aba bersedia, peserta berdiri diatas terompah dengan jari - jari kaki masuk kedalalm setengah lingkaran karet dan berpegangan satu sama lain. Sebaiknya para peserta memakai sepatu olahraga agar kaki tidak lecet. Peserta regu berpegangan satu sama lain, boleh pada bahu atau pinggang;

h. Aba - aba siap, peserta siap untuk melakukan jalan;

i. Aba - aba ya, peserta berjalan secepat - cepatnya menempuh jarak 50 meter.

j. Regu dianggap sah, apabila peserta terakhir dan ujung terompah bagian belakang melewati garis finish dengan tidak ada kesalahan selama dalam perjalanan. Regu juga masih dianggap sah, walaupun regu tersebut jatuh kedepan tetapi kedua kaki masih kontak pada terompah meskipun tangan menyentuh tanah;

k. Peserta/regu dianggap gugur apabila,tidak berhasil mencapai garis finish,menginjak lintasan peserta lain, dengan sengaja mengganggu peserta lain, salah satu kaki atau kedua kaki menginjak tanah artinya salah satu kaki atau kedua kaki tidak ada kontak dengan terompah, terompah rusak ditengah jalan, regu yang gugur tidak perlu meneruskan sampai garis finish.

Permainan Bakiak berfungsi untuk meningkatkan aspek fisik dan aspek keterampilan sosial anak usia dini. Dengan bermain bakiak, otot-otot kaki anak akan terlatih kekuatan dan keseimbangannya. Pada aspek perkembangan sosial anak dapat membina hubungan dengan anak lain, anak dapat belajar arti menghargai teman, , tidak ingin menang sendiri, saling membantu, belajar menanti giliran, serta belajar meminta izin untuk ikut bermain. Disini tentu anak akan belajar bagaimana menghargai hak orang lain, perasaan dan benda milik orang lain serta belajar besabar menanti giliran untuk melaksanakan suatu aktivitas atau kegiatan. Anak juga diajarkan belajar berdekatan dengan anak lain tanpa mengganggu, berkomunikasi secara verbal maupun non verbal serta belajar menerima kekalahan.

\section{Lompat Tali}

Lompat tali dalam hal ini biasanya dengan menggunakan karet sangat populer dikalangan anak-anak era tahun 70-an hingga 90-an. Permainan lompat tali ini menjadi permainan yang sangat digemari saat main di sekolah atau dirumah. Biasanya tali yang digunakan untuk permainan lompat tali ini di buat dari ronceaan tali dari karet gelang. Lompat tali akan mengasah kekreatifan seorang anak dalam menjalin karet yang akan dipergunakan pada permainan tersebut.

Tidak ada yang mengetahui secara pasti kapan dan dari mana permainan ini berasal. Namun, permainan lompat tali sudah muncul sejak Belanda menjajah Indonesia, awalnya permainan ini dimainkan oleh anak-anak Belanda yang ada di Indonesia. Tetapi, ada pula yang mengatakan bahwa asal permainan lompat tali dari benua Eropa yang kemudian menyebar ke benua-benua lainnya termasuk di benua Asia Tenggara yakni tepatnya di Indonesia. Di Indonesia sendiri permainan ini banyak dijumpai di berbagai daerah namun dengan nama yang berbeda-beda. Misalnya seperti, nama Yeye, Tali Merdeka, Lompatan, Lompat Tali, dan lainlain (goodnewsfromindonesia.id). 
Cara melakukan permainan lompat tali yaitu sebagai berikut:

a. Pertama, sesuaikan dahulu karet tali dengan tinggi badan pemain. Caranya berdiri sambil menginjak bagian tengah tali dan tarik ujung-ujung disamping badan. Panjang tali sudah pas jika ujung tali yang di pegang sampai di ketiak.

b. Kedua, karet tali dipegang erat dengan posisi lengan atas rapat dengan tubuh dan siku sejajar dipinggang. Kemudian berdiri dengan posisi agak jinjit dan lutut sedikit di tekuk. Usahakan kepala tetap tegak tapi tetap rileks serta pandangan lurus ke depan.

c. Ketiga, pergelangan tangan digerakkan untuk memutar tali, lompatan tidak terlalu tinggi saat tali menyentuh lantai, tinggi lompatan miximal $2,5 \mathrm{~cm}$ dari lantai. Pertahankan posisi agak jinjit saat mendarat dan tumit jangan menyentuh lantai

d. Keempat, sebaiknya jika baru memulai permainan ini lakukan secara bertahap baru jika baru pandai biasa melakukan kombinasi gerakan.

Adapun aspek-aspek perkembangan anak yang dapat diperoleh dan dikembangkan dalam permainan ini yaitu sebagai berikut:

a. Motorik kasar

Dengan bermain lompat tali, motorik kasar akan terstimulasi. Anak menjadi lebih terampil karena mempelajari cara dan teknik melompat yang dalam permainan ini memerlukan keterampilan tersendiri. Lama-kelamaan tumbuh menjadi anak yang cekatan, tangkas dan dinamis. Otot-ototnya pun padat dan berisi, kuat, tangkas serta terlatip. Lompat tali bisa mengurangi obesitas pada anak.

b. Emosi

Lompat tali juga bisa melatih aspek emosi anak. Untuk melakukan suatu lompatan dengan tinggi dan benar, tentu dibutuhkan keberanian dari diri anak itu sendiri. Secara emosi ia di tuntut untuk membuat suatu keputusan besar dan berlatih untuk mengontrol emosinya. Karena kalau terlalu bersemangatpun akan membahayakan sendiri.

c. Ketelitian dan akurasi

Dengan melompat menggunakan tali, anak dapat belajar melihat suatu ketepatan dan ketelitian. Ketika tali diayunkan ia harus dapat melompat sedemikian lupa sehingga tak dapat terjerat tali dengan berusaha mengikuti ritme ayunan.

d. Sosialisasi

Selain bermain sendiri, lompat tali juga dapat dimainkan secara berkelompok. Bermain tali secara berkelompok membuat anak membutuhkan teman yang artinya dia juga belajar untuk bersosialisasi. Ia juga dapat belajar berempati, bergiliran, menaati peraturan dan lain-lain.

e. Intelektual

Saat melakukan lompatan terkadang anak juga perlu berhitung secara matematis agar lompatannya sesuai dengan jumlah yang telah di tentukan sesuai dengan aturan permainan

\section{Telfon Kaleng}

Salah satu bentuk permainan yang dirasa mampu meningkatkan aspek perkembangan bahasa anak adalah Telfon Kaleng. Telfon sebagai media mengoptimalkan kemampuan berbahasa anak adalah suatu permainan sederhana namun mempunyai pengaruh dan manfaat bagi perkembangan bahasa anak secara signifikan. Permainan ini selain melatih kemampuan bahasa anak juga melatih untuk berbicara dengan bahasa yang baik dan benar serta mudah dimengerti melalui dialog dengan teman yang dilakukan dengan menggunakan kaleng sebagai alat berkomunikasi. Bahasa digunakan untuk mengungkapkan suatu permintaan atau mengungkapkan suatu perasaan. Jika perkembangan bahasa anak kurang optimal maka dalam penyampainya bahasa sulit untuk dimengerti oleh orang lain, maka dari itu latihan berbahasa sangatlah penting untuk anak apalagi untuk anak usia dini. 
Sejarah mencatat percobaan pertama telepon kaleng dilakukan oleh Robert Hooke seorang fisikawan dan polymath asal Inggris. Selama tahun 1664-1665 Hooke bereksperimen dengan transmisi suara menggunakan kawat. Awal tahun 1667 Hooke berhasil membuat telepon kaleng. Dalam periode waktu yang singkat telepon kaleng sempat dipasarkan secara komersial, mengisi "kekosongan pasar" telepon listrik dari Alexander Graham Bell. Saat paten Bell "berakhir", telepon listrik kemudian mengalami perkembangan inovasi yang hebat. Persis seperti telepon yang kita kenal sekarang. Telepon kaleng pun tak lagi dijual secara komersial. Telepon kaleng justru populer di lingkungan pendidikan. Di sekolah-sekolah, telepon kaleng diajarkan sebagai salah satu alat bermain sekaligus belajar akan prinsip gelombang suara (hptekno.com).

Bahan untuk membuat telpon kaleng cukup sederhana dan mudah didapatkan. Yaitu terdiri dari dua kaleng dan benang, lalu hubungkan kaleng dengan benang melalui lubang (buat suatu cara agar benang tidak lepas dari kaleng, misalnya benang dikaitkan dengan paper clip agar tak lepas dari lubang). Setelah telepon kaleng dibuat, bersuaralah atau berkomunikasilah dengan cara menegangkan benang diantara dua kaleng lalu akan mendengar suara melalui kaleng. Bila benang dalam keadan renggang, suara tidak akan terdengar di kaleng.

Permainan telepon kaleng seperti ini sangat bermanfaat bagi anak. Keuntungan permainan telepon kaleng yaitu selain cara pembuatannya pun mudah dan tidak mahal, permainan ini juga dapat mengajarkan anak mandiri, fokus, mengajarkan cara berkomunikasi yang baik dan benar dengan menggunakan permainan telepon kaleng, agar anak dapat menggungkapkan suatu pendapat atau permintaan kepada teman/orang lain dengan sopan, baik dan jelas dan sesuai dengan peraturan.

4. Petak Umpet

Petak umpet atau dalam bahasa Inggris "Hide and Seek" adalah salah satu permainan tradisional anak-anak yang sudah sangat terkenal bahkan bisa dikatakan paling terkenal di dunia. Nyatanya, selain di Indonesia permainan ini juga sangat digemari oleh anak-anak di luar negeri. Jenis permainan ini sangat populer dibanding permainan tradisional yang lainnya karena permainan ini tidak memerlukan alat dan bahan khusus seperti permainan tradisional lainnya. Sejarah petak umpet diperkirakan sudah ada sejak abad ke 2 setelah masehi. Tapi hingga saat ini masih sulit untuk menemukan dari daerah mana permainan ini berasal. Namun menurut Encyclopedia Britannica, permainan ini pernah tertulis dalam sebuah karya penulis asal Yunani yakni Julius Pollux ketika ada jenis permainan serupa yang disebut dengan Apodidraskinda. Sekarang, di Yunani sendiri permainan jenis ini disebut sebagai Kryfto yang dianggap sama dengan model permainan petak umpet. Di Spanyol terkenal dengan nama Escondite. Di Perancis juga disebut dengan Jeu de Cache-Cache. Di Korea juga permainan petak umpet dikenal dengan nama Sumbagoggil. Di Indonesia sendiri, yang terkenal adalah penyebutan permainan petak umpet dalam bahasa Sunda dan bahasa Jawa. Dalam bahasa Sunda, petak umpet dikenal dengan istilah Ucing Sumput sedangkan dalam Bahasa Jawa disebut dengan Dhelikan, Jethungan, atau Jepungan (apasih.web.id).

Permainan ini sangat mengasikan dan juga banyak manfaatnya. Dalam pengaplikasiannya, permainan ini cukup mudah dalam melakukannya yaitu hanya membutuhkan 3-6 anak meskipun seringkali lebih dari itu. 1 (satu) anak bertugas sebagai pencari kemudian menghitung angka 1 sampai 10 sambil menutup mata dan biasanya sambil bersender ke tiang atau dinding sebagai "benteng" dan anak-anak yang lainnya cepat-cepat bersembunyi. Pada hitungan ke 10 pencari membuka mata dan mencari teman-temannya dimana mereka bersembunyi.

Berdasarkan proses permainan petak umpet di atas, banyak sekali manfaat yang dihasilkan salah satunya adalah aspek perkembangan berfikir (kognitif) anak. Perkembangan berfikir pada anak itu ditandai dengan suatu kemampuan untuk merencanakan, menjalankan 
suatu strategi untuk mengingat dan untuk mencari solusi terhadap suatu permasalahan. Hal ini sejalan dengan yang diungkapkan oleh Piaget (Budiningsih, 2004, p. 35), yaitu proses belajar terjadi antara lain mencakup pengetahuan stimulasi yang diterima dan menyesuaikan struktur kognitif yang sudah dimiliki dan terbentuk di dalam pikiran anak berdasarkan pemahaman anak dan pengalaman-pengalaman sebelumnya.

Manfaat tersebut dapat dilihat dari cara proses permainan petak umpet, misalnya anak akan berlari dan bersembunyi sehingga secara tidak langsung anak berfikir dan melakukan olahraga. Letak perpikirnya ada pada saat anak bersembunyi, ia akan berfikir dan mencari tempat yang menurutnya aman dan sulit untuk ditemukan oleh temannya yang bertugas sebagai pencari. Selanjutnya yaitu secara tidak langsung anak akan belajar menghitung, hal ini dikarenakan pada permainan ini anak-anak yang bermain dibagi menjadi 2 peran yaitu berperan sebagai pencari dan yang akan dicari. Saat anak mendapatkan kesempatan menjadi pencari, tentu ia akan menyebutkan hitungan untuk memberikan kesempatan kepada anak-anak yang bersembunyi, kognitif anak akan terasah (tribunnews.com).

Jenis permainan ini juga dapat membantu anak saling bersosialisasi dengan lingkungan dan teman-temannya. Ini artinya permainan ini akan mengasah aspek perkembangan sosial emosional anak. Selain itu petak umpet juga membantu anak aktif bergerak yang sangat bermanfaat bagi kesehatan dan pertumbuhan. Anak akan banyak bergerak dan berlari saat buruburu bersembunyi dan berlomba menuju "rumah" (base). Anak juga dapat dilatih tentang sportivitas dan fair play. pemain yang kalah akan bertugas mencari, sedangkan pemain lain bersembunyi. Anak akan belajar menerima kekalahan untuk dapat terus melanjutkan permainan. Masing-masing anak harus kreatif mencari ide persembunyian yang tidak sama dengan pemain lainnya. Bermain bersama membantu anak belajar mematuhi aturan. Setiap anak akan berusaha untuk mematuhi aturan yang disepakati bersama agar permainan dapat berlangsung dengan menyenangkan.

Itulah beberapa contoh permainan tradisional yang juga kebanyakan dimainkan bersamasama lebih dari satu orang, sehingga banyak terjadi interaksi dan sangat baik untuk melatih kerja sama, kejujuran, kebersamaan, dan saling menolong yang sangat baik untuk perkembangan sosio emosional anak. Terlepas dari itu, tentunya permainan tradisional maupun permainan modern ada sisi positif dan negatifnya. Dengan menggunakan permainan tradisional, maka secara tidak langsung ini merupakan upaya melestarikan warisan budaya dengan keberagaman yang tidak semua negara memilikinya. Sehingga permainan tradisional seharusnya memang dikenalkan lagi pada anak-anak agar mereka juga tahu betapa kayanya negeri ini, sehingga tumbuhlah rasa cinta kepada tanah airnya.

\section{SIMPULAN DAN SARAN}

Bimbingan konseling anak merupakan proses yang terjadi antara anak dan seorang konselor dalam hal ini guru/ pendamping yang membantu anak-anak untuk memahami apa yang telah terjadi kepada mereka serta untuk membantu anak mencapai perkembangan dan pertumbuhan yang optimal. Bimbingan dan konseling di lembaga PAUD tidak hanya diberikan kepada mereka yang mempunyai perilaku masalah, melainkan juga harus diberikan kepada anak yang sedang dalam proses pertumbuhan dan perkembangannya. Dengan demikian, pada prosesnya bimbingan konseling anak bukan hanya untuk mengatasi perilaku bermasalah pada anak didik, melainkan juga tindakan untuk memenuhi kebutuhan kembangnya secara maksimal sebagai sebuah langkah preventif.

Sejatinya, permainan tradisional dapat digunakan sebagai media bimbingan dan konseling bagi anak usia dini. Jenis permainan dalam permainan tradisional sangat baik untuk perkembangan anak seperti mengembangkan ketangkasan, kreatifitas, sosial, dan sebagainya. Permainan tradisional dihasilkan dari budaya yang bernilai bagi anak-anak dalam rangka 
menumbuhkembangkan kemampuan berfantasi, berkreasi, berolah raga dan juga sekaligus dapat dimanfaatkan sebagai sarana berlatih untuk hidup bermasyarakat, keterampilan, kesopanan serta ketangkasan.

Permainan tradisional sebagai satu aset budaya untuk menunjukkan ciri khas kebudayaan suatu bangsa, maka pendidikan karakter bisa dibentuk melalui permainan tradisional sejak usia dini. Permainan tradisional di Indonesia saat ini sudah jarang dimainkan oleh anak-anak. Permainan tradisional sudah banyak tergantikan oleh permainan modern sebagai salah satu akibat dari perkembangan teknologi yang sangat pesat. Dampaknya, anak-anak tumbuh menjadi manusia yang tidak memiliki karakter kuat, bahkan lebih kepada bertingkah laku mengikuti perkembangan zaman tanpa filter. Melalui permainan tradisional, diharapkan kemampuan dan psikis anak dapat berkembang secara optimal, sesuai dengan tujuan BK anak usia dini itu sendiri.

\section{AKNOWLEDGMENT}

Penelitian ini didukung oleh STAI Sufyan Tsauri Majenang.

\section{DAFTAR RUJUKAN}

Adhiputra, Anak Agung Ngurap. 2013. Bimbingan Konseling Aplikasi di SD dan TK. Yogyakarta: Graha Ilmu.

Arikunto, Suharsimi. 2015. Manajeman Penelitian. Jakarta: PT Rineka Cipta.

Budiningsih, Asri. 2004. Belajar dan Pembelajaran. Yogyakarta: Rineka Cipta

Geldard, Kathryn. 2011. Konseling Anak-Anak Panduan Praktis Edisi Ketiga. Yogyakarta: Pustaka Pelajar.

Geldard, Katryn. 2012. Konseling Anak-Anak. Jakarta: PT.Indeks.

Ismail, Andang. 2006. Education Games, Menjadi Cerdas dan Ceria dengan Permainan Edukatif. Yogyakarta: Pilar Media.

Iswantiningtyas, Veny. 2017. Layanan Bimbingan dan Konseling Bagi Anak Usia Dini. UM

(Malang) : Prosiding Seminar Bimbingan dan Konseling.Vol. 1, No. 1.

Khamdani, Ajun. 2010. Olahraga Tradisional. Kalimantan: PT. Maraga Borneo Tarigas.

Muhadjir, Noeng. 1998. Metodologi Penelitian Kualitatif. Bandung : PT Remaja Rosda Karya

Prantoro, Gian. 2015. Pengaruh Penggunaan Permainan Tradisional Bakiak Dan Engklek

Terhadap Peningkatan Keterampilan Sosial Anak Usia Dini. Skripsi FIP UN Yogyakarta.

Pontjopoetro, S. Dkk. 2002. Permainan Anak, Tradisional dan Aktivitas Ritmik. (Modul). Jakarta.

Pusat Penerbitan UT

\section{AUTHOR}

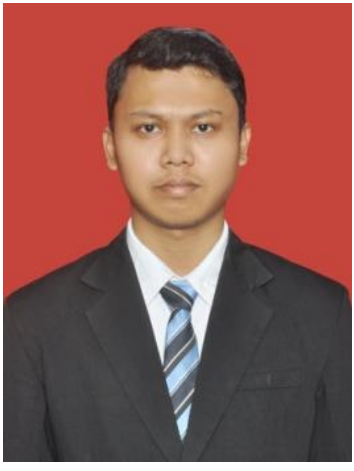

Frendi Fernando, dari Sekolah Tinggi Agama Islam (STAI) Sufyan Tsauri Majenang Nama Lengkap Alamat

Telepon / Hp

Institusi

E-mail

Sinta ID

Google Scholar ID
: Frendi Fernando, MA

: RT 01/ RW 12, Padangjaya, Kec. Majenang, Cilacap

: 082325842955.

: STAI Sufyan Tsauri Majenang, Cilacap

frendifernando@gmail.com

6682097 (FRENDI FERNANDO)

: Frendi Fernando 